\title{
Kimian States: The Case of Stative Passive Participles Corresponding to Roz- Object Experiencer Verbs in Polish*
}

\begin{abstract}
In this text we consider properties of stative passive participles corresponding to roz- Object Experiencer verbs in Polish. They are viewed in the light of the distinction between Davidsonian states (Davidson 1967) and Kimian states (Kim 1976). Polish statives with rozpassive participles seem to show features of both Kimian and Davidsonian states. We will consider the results of various tests proposed in the literature to discover the properties of the relevant Polish structures and offer an explanation for the areas in which roz-structures diverge from the characteristics of Kimian states.
\end{abstract}

\section{Keywords}

Kimian states, Davidsonian states, stative, participles, Object Experiencer verbs, Polish

\section{Streszczenie}

Tekst poświęcony jest analizie imiesłowów biernych z przedrostkiem roz-, utworzonych od czasowników stanu z nosicielem stanu w funkcji dopełnienia. Wyrażenia $\mathrm{z}$ imiesłowami biernymi badanych czasowników posiadają zarówno cechy stanów Davidsona (1967), jak i stanów Kima (1976). W poniższym artykule dajemy odpowiedź na pytanie o status tych struktur. Proponujemy także wyjaśnienie faktów, które stoją w sprzeczności z uznaniem polskich konstrukcji za stany Kima.

\section{Słowa kluczowe}

Stany Kima, Stany Davidsona, statyczny, imiesłowy, czasowniki stanu z nosicielem stanu $\mathrm{w}$ funkcji dopełnienia, język polski

" I would like to express my gratitude to the anonymous SPL reviewers for their numerous insightful comments, which made me rethink many of the claims presented here. Their help has been invaluable and constitutes food for much future thought. 


\section{Introduction}

In this text we discuss a representative class of structures with passive participles in Polish which present a problem as to their classification. On the face of it, structures with these passive participles have mixed features of Davidsonian states and Kimian states. We will opt for an analysis which depicts them as Kimian states, i.e. states without event implications. The text will be organized as follows: Section 1 will briefly discuss the idea of Davidsonian states and Kimian states. Section 2 will introduce Polish data relevant to the subject. Section 3 will present pros and cons of Kimian state analysis of stative roz-passives, to be concluded with the claim that roz-passives are Kimian states indeed.

\section{Davidsonian states vs. Kimian states}

Davidson (1967) put forward the claim for an additional (covert) event argument in the semantic representation of action predicates. His claim can be represented by the following logical notation based on Maienborn (2019: 51):

(1) $\mathrm{G} e[$ PREDICATE(argument1, argument2,e)]

In this notation, a transitive predicate discharges three arguments, i.e. argument $_{1}$, argument ${ }_{2}$ and event itself (represented above as $e$ ). The first two arguments are introduced via thematic roles of AGENT and PATIENT and they roughly correspond to the syntactic notions of subject and object.

Neo-Davidsonians (inter alia: Higginbotham 1983, 1985; Parsons 1990, 2000; Higginbotham and Ramchand 1997) diverge from Davidson's original ideas in two basic ways. First, event arguments are discharged, according to them, not only by action predicates but by all verbal predicates, or even by all predicative categories, including prepositions, predicatively used adjectives and nouns (cf. Higginbotham and Ramchand 1997: 54). So the original idea of Davidson has been significantly extended to a much larger set of propositions. Importantly for the present text, event arguments are arguments of states as well (cf. Higginbotham 1983; Parsons 1990). ${ }^{1}$

\footnotetext{
${ }^{1}$ For instance, Higginbotham (1985: 555) includes the position E in the thematic grid of see. This position corresponds to the "hidden" argument called situation. The presence of a similar argument is argued for the NP (p. 588): John's lack of talent (in the sentence: Mary persuaded me of John's lack of talent). Higginbotham also specifies the position of $\mathrm{E}$ in the thematic grid at the node where VP meets Inflection marker (p. 561). Higginbotham (2000) explicitly includes states under the heading of events and uses the term situation to refer to all eventualities.

Neo-Davidsonians do not abandon the distinction between states and other eventualities altogether. E.g. Parsons (1990) equips states with predicate HOLD in their logical representations, which sets them apart from CUL(minated) logical representations of culminating events. Parsons (2000) argues for the predicate of state in a variety of stative constructions.
} 
Unlike in Davidson's model, the event argument is not an additional covert argument discharged by a predicate, on a par with such arguments as subject or objects, but it is the only argument, while other participants in the predication are introduced by means of thematic roles or some kind of structural decomposition. As a consequence, the logical differentiation of arguments proper (subject, object(s)) and modifiers has been abolished. ${ }^{2}$

What is immediately relevant to our paper is the position that researchers take with respect to the status and representation of states in the Post-Davidsonian arena of linguistics.

One position, taken by Ramchand (2005), is that states do not differ ontologically from other, less controversial, eventive eventualities (headed by dynamic verbs). Simply put, eventualities of different kinds manifest different properties thanks to additional elements in their representations. Ramchand (2005: 363) spells this claim as follows: "event variable is still the basic variable type that is at the basis of the clause, but it is subject to internal complexity and it is modified/updated through various functional projections." The properties that all eventualities have in common and which are critical to their being eventualities are "the constitutive participants, the accessibility to higher cognitive operations, and the inherent locatability in time" (Ramchand 2005: 364).

This theoretical stance is questioned by Maienborn $(2003,2005,2019)$, who insists that a significant difference in the properties of particular predications calls for assuming the existence of a fundamental typological chasm: some eventualities (spelled out by statives and copula constructions) are abstract objects, inaccessible to direct perception, and - as a result - excluded as infinitival complements of perception verbs. As abstract objects, they do not take locative or event-related manner modifiers. Instead of event arguments, statives have abstract object arguments. Thus, one should posit Kimian states (K-states, in reference to Kim 1976) - without event arguments. Maienborn (2005) claims that copula sentences and statives possess the above characteristics and should be considered K-states. As examples of statives she mentions such verbs as: know, hate and resemble, while sit, sleep and lie represent D-states.

Zhou (2019) notes that not all states are the same, even with HOLD in their representations. For instance, progressive sentences may express an aim in their semantics, while some other states, e.g. know, do not. Consequently, introducing more semantic primitives to account for all relevant distinctions may be unavoidable within Neo-Davidsonianism.

${ }^{2}$ Maienborn (2019: 57) supplies the following logical notation for the sentence: Jones buttered the toast in the bathroom with the knife at midnight as a consequence of Neo-Davidsonian approach to event arguments:

马 $e[\operatorname{BUTTER}(e) \& \operatorname{AGENT}(e$, jones) \& PATIENT $(e$, toast $) \& \operatorname{IN}(e$, the bathroom) \& INSTR (e, knife) \& $\mathrm{AT}(e$, midnight)

Thus, all the relations between the event and its participants (also these traditionally classed as modifiers, not arguments) are on the same footing. 
Maienborn (2019: 71) sums up the characteristics distinguishing K-states from D-states as follows:

(2) Linguistic diagnostics for Kimian states:

a. K-state expressions cannot serve as infinitival complements of perception verbs and do not combine with locative modifiers, manner adverbials, and further participant expressions.

b. K-state expressions combine with temporal modifiers.

c. K-state expressions are accessible for anaphoric reference.

d. The result of negating a $\mathrm{K}$-state expression is again a $\mathrm{K}$-state expression.

The most revealing features of K-states are exemplified below, where the ungrammatical examples with $\mathrm{K}$-states in $(3 \mathrm{a}, 4 \mathrm{a}, 5 \mathrm{a})$ are quoted after Maienborn (2005), and they are juxtaposed with the grammatical D-states in (3b, 4b, 5b).

First, K-states cannot constitute infinitival complements of perception verbs (Maienborn 2005: 284), as the example with wissen 'know' shows, while D-states (schlafen 'sleep') can:

(3) (a) ${ }^{*}$ Ich hörte Carol die Antwort wissen.

I heard Carol the answer know

(b) Ich sah Carol schlafen.

I saw Carol sleep

'I saw Carol sleep'.

Wissen 'know' cannot appear with eventuality-related locative modifiers either (Maienborn 2005: 294), but liegen 'lie' (a D-state) can:³
(a) ${ }^{\star}$ Carol weiß (gerade)
an der Tafel
die Antwort.
Carol knows (at the moment) at the blackboard the answer

(b) Carol liegt (gerade) auf dem Bett.

Carol lies (at the moment) on the bed

'Carol is lying on the bed at the moment.'

${ }^{3}$ Maienborn (2005: 288-289) draws a distinction between frame-setting and eventualityrelated modifiers. The former "provide a semantically underspecified domain restriction for the overall proposition." Consequently, they can be freely interpreted and do not place the event/ state at a specific location. Maienborn (2005: 289) gives the following example of a frame-setting modifier:

weil Diego Armando Maradona in Italien (leider) verheiratet war.

because Diego Armando Maradona in Italy (unfortunately) married was.

As a frame-setting locative, in Italien can be interpreted in various ways. Maienborn supplies the following interpretations: $a$. When he was in Italy, Maradona was married (temporal reading), b. According to the laws in Italy, Maradona was married. c. According to the belief of the people in Italy, Maradona was married. K-states can co-occur with frame-setting modifiers, as these are not eventuality related. 
Similarly, statives, like besitzen 'own' or ähneln 'resemble', do not combine with manner adverbials, comitatives, and other phrases that modify the internal structure of events (Maienborn 2005: 294; see also Maienborn and Schäfer 2011), but D-state sitzen 'sit' is grammatical in such constructions:

(5) (a) ${ }^{*}$ Paul besitzt sparsam/spendabel viel Geld. (manner adverb) Paul owns thriftily/generously much money

*Maria ähnelt mit ihrer Tochter Romy Schneider. (comitative) Maria resembles with her daughter Romy Schneider

(b) Paul sitz ruhig/gemütlich/geduldig.

(manner adverb)

Paul sits quietly/comfortably/patiently

'Paul sits quietly/comfortably/patiently'

Maria sitzt mit ihrer Tochter.

(comitative)

Maria sits with her daughter

'Maria sits with her daughter.'

Another difference between $\mathrm{D}$-states and K-states becomes visible when they are negated. Negated K-states are still K-states, so they combine with temporal modifiers (Maienborn 2005: 310):

(6) Carol war nicht im Studio und zwar eine Stunde lang.

Carol was not in.the studio and "in fact" for one hour

'In fact, Carol was not in the studio for an hour.'

Negated D-states do not express D-states anymore. Thus they are ungrammatical with locative and manner modifiers, as well as with comitatives:

(7) Paul wartete (*nicht) auf den Bus, und zwar dort/lässig/mit Carol. Paul waited ( ${ }^{*}$ not) for the bus, "in fact" there/coolly/with Carol 'In fact, Paul (did not) wait for a bus there/coolly/with Carol.'

In view of the dichotomy of states, Maienborn $(2005,2019: 71)$ stresses the necessity of distinguishing a separate ontological category of states, i.e. K-states, which do not have the event argument in their semantics:

(8) K-states are abstract objects for the exemplification of a property $P$ at a holder $x$ and a time $t$.

To support the analysis of K-states as abstract object arguments, Maienborn (2005: 301-302) brings forth the use of anaphoric elements, such as das 'it' and dabei 'thereat', which refer back to K-states and lay bare their conceptual status as objects in the examples quoted below:

(9) Carol ist wütend. Das wird bald vorbei sein.

'Carol is angry. This will soon over be.'

Es war kalt und dabei regnerisch.

'It was cold and thereat rainy.' 
The anaphors do not distinguish K-states from D-states. As Davidson (1967) himself notes, anaphoric expressions, like it, refer back to events, justifying their treatment as arguments in logical formulae. The use of das and dabei as anaphoric expressions of $\mathrm{K}$-states provides evidence that $\mathrm{K}$-states are also arguments and objects. In Maienborn's (2019: 74) words, the anaphoric expressions prove that: "K-states have ontological content beyond a mere temporal dimension." Das and dabei refer back to the 'substance' (cf. also Maienborn 2007 for details).

K-states possess characteristics that make them similar to Davidsonian eventualities, i. e. they have a temporal dimension, and to facts - as abstract objects, i.e. purely mental constructs useful in communication (Maienborn 2005: 303).

Although Maienborn's (2005) analysis has attracted a lot of criticism (cf. e.g. Engelberg 2005; Higginbotham 2005; Ramchand 2005; Rothstein 2005; Ernst 2016), we find her approach illuminating when applied to Polish structures with roz-passive participles.

\section{Stative structures with passive participles of Polish Object Experiencer verbs prefixed with roz-}

\subsection{Object Experiencer verbs with roz-}

Our body of data consists of constructions containing passive participles of a subclass of Object Experiencer verbs prefixed with roz-. ${ }^{4}$ According to Grafmiller (2013), Object Experiencer verbs (OEVs) discharge two arguments: Experiencer, an argument whose emotions are referred to, and Stimulus, which evokes these emotions. Unlike in canonical transitive structures (cf. Keenan 1976), the sentient argument (Experiencer) is discharged in the object position, while the subject argument assumes the role of Stimulus, which constitutes a puzzling assignment, since the allocation of Stimulus to the subject position, in view of a sentient argument being available, violates the hierarchies proposed for the assignment of verbal arguments to syntactic phrases (Perlmutter and Postal 1984; Baker 1988; Belletti and Rizzi 1988; Grimshaw 1990; Landau 2010, inter alia).

OEVs do not form a uniform class, as they can be divided into agentive and non-agentive predicates (cf. Grimshaw 1990) depending on the function of Stimulus: Agentive OEVs are diagnosed if Stimulus is a volitional causer of an emotion, and non-agentive OEVs - if Stimulus is non-volitional. Further, non-agentive OEVs can be eventive or stative.

\footnotetext{
${ }^{4}$ An extensive analysis of the relevant class of verbs and their passive structures is presented in Malicka-Kleparska (2019).
} 
Stative OEVs code situations in which Experiencer persists in a state as long as Stimulus and state are co-extensive (cf. Arad 1998: 206). These verbs do not form grammatical verbal passives (Grimshaw 1990; Pesetsky 1995; Landau 2010). Eventive OEVs have Stimulae producing mental changes in Experiencers and they may or may not have corresponding passives depending on a language and the degree to which a verb is eventive (cf. Landau 2010 in particular).

Roz- OEVs belong to this last group, i.e. they are eventive. They form a numerous and consistent semantic group with uniform morphological formatives. Consequently, they should constitute good material for a linguistic analysis.

Szymanek (2010: 168) describes the verbs as possessing "evolutive' reading, [...] combined with a tinge of inceptive meaning." Below we supply an almost exhaustive list of such predicates in Polish:

(10) rozanielić 'make [sb] blissful', rozbestwić 'enrage', rozbudzić 'arouse', rozzuchwalić 'encourage', rozckliwić 'make [sb] feel susceptible', rozchwiać 'upset', rozczarować 'disappoint', rozczulić 'make [sb] feel touched', rozdrażnić 'annoy', rozśmieszyć 'amuse', rozentuzjazmować 'excite', rozerwać 'amuse', rozżewnić 'make [sb] feel sentimental', rozeźlić 'make [sb] angry', rozgniewać enrage', rozgoraczkować 'make [sb] agitated', rozhisteryzować 'make [sb] hysterical', rozjątrzyć 'exacerbate', rozjuszyć 'enrage', rozkaprysić 'make [sb] feel finicky', rozkrochmalić 'make [sb] feel touched', rozleniwić 'make [sb] feel indolent', rozmarzyć 'make [sb] feel dreamy', roznamiętnić 'arouse passion', rozochocić 'make [sb] feel merry', rozpieścić 'spoil', rozpogodzić 'cheer [sb] up', rozproszyć 'distract', rozprężyć 'relax', rozpuścić 'spoil', rozzłościć 'make [sb] angry', rozżewnić 'make [sb] feel sentimental', rozsierdzić 'infuriate', roztkliwić 'move', rozweselić 'cheer [sb] up', rozwścieczyć 'infuriate', rozzuchwalić 'make [sb] feel audacious'.

Some of the verbs in the list above are infrequent (e.g. rozbestwić 'enrage', rozgoraczkować 'make [sb] agitated', rozkaprysić 'make [sb] feel finicky'); some are OEVs in only one meaning (e.g. rozchwiać 'upset mentally' vs. 'upset physically', rozerwać 'amuse' vs. 'tear somebody or something apart'); some do not have corresponding passive participles with the relevant sense (rozerwać 'amuse' - rozerwany 'torn physically apart'). All of them, however, are quoted in Narodowy Korpus Języka Polskiego (NKJP) in the relevant contexts, i.e. with non-agentive Stimulae (Przepiórkowski et al. 2012).

Roz-makes these verbs perfective (while some have secondary imperfectives, e.g. rozweselić 'cheer.PRF one up' vs. rozweselać 'cheer.IMPRF one up). ${ }^{6}$

\footnotetext{
${ }^{5}$ The term 'evolutive' (ewolutywny in Polish) is explained by Wróbel (1984: 488) as referring to the process of achieving or coming into a state gradually.

${ }^{6}$ Below we supply the list of abbreviations used here to refer to different grammatical categories: NOM - nominative, GEN - genitive, ACC - accusative, INS - instrumental, LOC - locative, PRF - perfective, IMPRF - imperfective, PASS - passive, PTCP - participle, REFL - reflexive.
} 
Most roz- verbs do not possess prefixless imperfective variants, but, on the basis of these that do, we may deduce that the contribution of the prefix amounts to the inchoative semantics, e.g.: rozkaprysić 'make one feel finicky' - kaprysić 'grumble'; rozzłościć 'infuriate' - złościć 'annoy'. Meanings of some roz- OEVs cannot be simply deduced from the meanings of their roots plus the prefix, e.g.: rozpuścić 'spoil' - puścić 'let go', rozpieścić 'spoil' - pieścić 'fondle. However, their constant features are OEV properties, perfective aspect and inchoative semantics. They differ from stative OEVs in that they code not only the state, but also the event leading up to the state. Consequently, they can be modified by event-related modifiers, such as szybko 'quickly' or powoli 'slowly' (11), unlike stative OEVs (12):

(11) Związek szybko/powoli rozczarowat dziewczynę. relationship.NOM quickly/slowly disappointed girl.ACC 'The relationship quickly/slowly disappointed the girl.'

(12) Bezczynność ${ }^{*}$ szybko/*powoli gnębiła dziewczynę. idleness.NOM quickly/slowly depressed girl.ACC

The question may arise whether szybko 'quickly' and powoli 'slowly' really modify the event itself, and not the progression of time leading up to the event. The answer can be found in sentences like (13) below:

(13) ${ }^{\star}$ Wynik nie rozczarowat dziewczyny, $i$ to szybko. result.NOM not disappointed girl.GEN and this quickly

(13) is ungrammatical, verging on the sentence that cannot be processed at all, because the event did not take place although some time may have elapsed. As expected, the progression of time itself is not enough to support adverbial modification (for details see Maienborn and Schäfer 2011: 1399).

As OEVs are eventive predicates, we could expect passive constructions with such verbs to be eventive as well. However, in the next subsection we will show that roz-passives have mixed properties of D-states (with event implications) and K-states (without event implications).

\subsection{Stative passives with roz-participles}

In this section we will concentrate on passive structures with roz-participles and the auxiliary być 'be'. Although in Polish we have also auxliary zostać 'become', which forms passives, zostać 'become' brings about eventive reading of a structure and consequently passives with zostać 'become' are not good candidates to be considered as K-states (for distinct properties of być 'be' and zostać 'become' passives see Laskowski 1984; Zdziebko 2017; Bondaruk and Rozwadowska 2018, inter alia). 
A roz- passive structure with auxiliary być 'be' is illustrated in (14) below:

(14) Anna jest rozmarzona (wakacjami).

Anna.NOM is dreamy.PASS.PTCP.NOM holidays.INS

'Anna is dreamy (because of holidays).'

The subject argument represents Experiencer in (14) above and corresponds to the object in (15) below:

(15) Wakacyjne plany rozmarzyły Annę.

holiday.NOM plans.NOM made.dreamy Anna.ACC

'Holiday plans made Anna dreamy'.

Sources dealing with Polish morphosyntax treat structures in (14) as representing statives (or adjectival passives - an alternative term, see e.g. Laskowski 1984; Zdziebko 2017; Bondaruk and Rozwadowska 2018). Their stative character can be verified both semantically and grammatically.

Semantically, states are homogenous down to instants (cf. Rothstein 2004, inter alia). In (14) every part of the state of being disappointed counts as the state of being disappointed, and nothing else. This semantics distinguishes states from achievements and accomplishments. Activities may also be considered homogenous if we disregard the fact that they may be broken into minimal events, which themselves are "minimal changes of state or movement" (cf. Rothstein 2004: 20).

The identity of states can be probed with a variety of syntactic tests proposed by e.g. Vendler (1957), Dowty (1979) or Smith (1999). Here we will quote just these which work best for the Polish material. ${ }^{7}$

States cannot take such predicational manner adverbs as quickly (16) since these adverbs specify the manner in which an event develops (but other groups of manner adverbs are admissible, e.g. subject-oriented or speaker-oriented ones - for details see e.g. Maienborn and Schäfer 2011). Similarly, states cannot appear in the imperative form (17), or as complements of verbs like force (18), nor can they occur in pseudo-cleft constructions ('What X could do was Y') (19):

(16) *Anna jest szybko rozmarzona. Anna.Nom is quickly dreamy.Nom

The tests illustrated in (17), (18) are really agentivity tests (cf. Levin 2009). However, since at least a subclass of states does not tolerate agents, the results of these tests, taken together with the remaining criteria, support the claim that the structures under consideration are states.

7 The progressive form test cannot be applied in Polish. 
(17) ${ }^{\star B a ̨ d z ́ ~ r o z m a r z o n a ! ~}{ }^{8}$

be dreamy.NOM

(18) *Jan zmusit Anne aby była rozmarzona.

Jan.Nom forced Anna.ACC in.order.to was dreamy.NOM

(19) ${ }^{\star}$ Co Anna potrafiła zrobić, to być rozmarzona. what Anna.NOM could do it be dreamy.Nom

Already at this point we may observe that roz- states diverge from typical D-states in some respects: D-state verbs, like spać 'sleep', behave differently in some of the contexts above:

(20) Śpij! (cf. (17))

sleep

'Sleep!'

(21) Jan zmusil Anne aby spała. (cf. (18))

Jan.Nom forced Anna.ACC in.order.to slept

'John forced Anna to sleep.'

(22) Co Anna potrafiła zrobić, to podnieść gałąź. (cf. (19))

what Anna.Nom could do it pick.up branch.ACC

'What Anna could do was to pick up a branch.'

As the tests show, the structures with roz-passive participles have basic characteristics of states. The next section will be devoted to the problem whether they should be treated as D-states (with event implications) or as K-states (without such implications). The fact that roz-passive participles correspond to eventive OEVs may point to the first possibility, while their semantics of "entities constituted just by the holding of the property (of some objects)" (Moltmann 2007: 370) points to the latter.

\section{Stative passives with roz- as Kimian states?}

In this section, we will check characteristics of passive structures with roz-participles against the properties of K-states as proposed by Maienborn (2005, 2019) and discussed in Section 1.

${ }^{8}$ Reviewer 1 quotes the sentence:

(i) Bądź częściej rozmarzona!

$\mathrm{Be}$ more.frequently dreamy.NOM

'Dream more frequently!'

as a case problematic for our analysis. Since the states we discuss are stage-level predications (Carlson 1977, Chierchia 1995), we think that in this case we are dealing with the phenomenon of coercion of a state into a series of events resulting in a series of states. 


\subsection{Kimian state properties of roz- passives}

Passive structures with roz-participles will be investigated in this section with the view to checking how they fare in the tests designed for K-statehood. We will check if they take temporal modifiers (cf. (6)), are ungrammatical with eventuality-related locative modifiers (cf. (4)) and manner adverbials (cf. (5)) or comitatives (cf. (5)). We will also examine whether negated roz-passives retain their properties, just like K-states (cf. (6)).

Not all the tests proposed for K-states are applicable to Polish. Verbs of perception do not take infinitival complements in Polish and that clauses ( $\dot{z} e$ clauses in Polish), which can complement such verbs, do not represent bare eventualities (events), but facts (cf. Maienborn 2005 for German and Bondaruk et al. 2017: 67-68 for Polish).

In relation to the last point, Reviewer 1 brought to our attention an example with a different complementizer than $\dot{z} e$ 'that', viz. jak 'how', which might represent a bare eventuality and which is grammatical with our passive structures, thus speaking against their K-state status:

(23) Widze, jak on jest rozczarowany.

I.can.see how he.NOM is disappointed.PAss.PTCP.NOM

'I can see how disappointed he is.'

In our opinion, jak 'how' clause in (23) does not illustrate a bare eventuality (testing for K-statehood), but it codes the degree to which somebody is disappointed and it is the degree which is the object of perception, and not the state itself.' In other words, an abstract object gets coerced into non-abstract reading that can be measured. ${ }^{10}$

Another phrase which might illustrate a bare eventuality complementing a perception verb in Polish has also been supplied by the same Reviewer:

(24) Widze go zdenerwowanego.

I.can.see himacc nervous.PAss.PTCP.ACC

'I can see him nervous.'

Depictive structures of this kind are discussed by Szajbel-Keck (2015), who offers an extensive analysis showing that depictives are adjuncts to the main clause and not complements of the lexical verb. As adjuncts, they do not qualify for testing K-states.

\footnotetext{
${ }^{9}$ A reading of (23) identical to that of a clause with $\dot{z} e$ 'that' is also possible, but this use is non-standard in Polish.

${ }^{10}$ Anderson and Mokrzycki (2015) analyse similar data with degree clauses and argue that they constitute kinds of D-states. However, their analysis does not make provisions for a possible distinction between $\mathrm{K}$-states and $\mathrm{D}$-states, and in its present form its implications for our analysis are unclear.
} 
Apart from the impracticable complementation tests discussed above, the remaining tests can be applied to Polish data.

As expected, roz-passives appear freely with temporal modifiers, except for modifiers that occur with achievements and accomplishments: ${ }^{11}$

(25) Anna była rozczarowana/rozzłoszczona/rozmarzona przez

Anna.Nom was disappointed/angry/dreamy.PASs.PTCP.NOM for

dwa dni/wczoraj.

two.ACC days.ACC/yesterday

'Anna was disappointed/angry/dreamy for two days/yesterday'.

If roz-states are K-states and K-states are abstract objects then it follows that roz-states cannot co-occur with locative adverbials modifying the eventuality (cf. ftn. 4). ${ }^{12}$

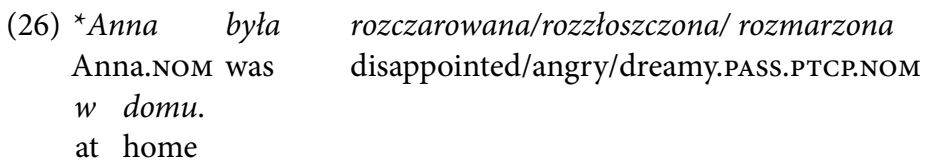

Manner adverbials are ungrammatical with roz- passives:

${ }^{11}$ Such modifiers as e.g. $w$ godzine 'in an hour' cannot accompany states of any kind as they signal telicity/completion of a predication - see e.g. Vendler (1957), Dowty (1979), Smith (1999).

${ }^{12}$ When we introduce a frame-setting locative modifier, the sentence becomes much more acceptable, as frame-setting adverbials modify the overall situation. Consider the example below:

(i) 'W Polsce Anna była rozczarowana.

in Poland.Loc Anna.Nom was disappointed.PAss.PTCP.NOM

'While in Poland Anna was disappointed.'

The placement of the adverbial seems to matter since grammaticality decreases if the locative is placed at the end of the sentence, the position more usual for modifiers of events:

(ii) * Anna była rozczarowana w Polsce.

Anna.nom was disappointed.PAss.PTCP.NOM in Poland.LoC

'Anna was disappointed in Poland.'

Reviewer 1 notes that the sentence in (iii) below becomes more acceptable if it is presented as a part of a contrast:

(iii)? Anna była rozmarzona w domu, ale $w$ pracy

Anna.Nom was dreamy.PAss.PTCP.NOM at home.Loc but at work.LOC

już nie.

already not

'Anna was dreamy at home but not at work.'

This increased acceptability should be attributed to the contrast of what happens at home and at work. The modifiers function here as referring to the time spent at home and at work, respectively, so in fact they are not locative, but temporal modifiers and temporal modifiers are acceptable with K-states. The temporal reading comes to the forth because of the contrast of leisure-time and working-time.

As roz- structures belong to the class of stage-level constructions (cf. Carlson 1977, Chierchia 1995), their locative modifiers are interpreted as temporal modifiers quite regularly (cf. Maienborn 2004 for discussion). 
(27) ${ }^{\star}$ Anna była szybko/powoli/spokojnie/nieruchomo

Anna.Nom was quickly/slowly/peacefully/motionlessly

rozczarowana/rozzłoszczona/rozmarzona.

disappointed/angry/dreamy.PAss.PTCP.NOM

D-states can take manner modifiers, but the selection depends on a particular lexical item and can be limited. However, spokojnie 'peacefully' and nieruchomo 'motionlessly', out of the selection given in (27), can co-occur with D-states:

(28) Anna spokojnie/nieruchomo spała/leżała/siedziała.

Anna.Nom peacefully/motionlessly slept/lay/sat

'Anna slept/lay/sat peacefully/motionelessly'.

Comitative phrases, interfering with the internal structure of events, are also banned in roz-passive structures:

(29) *Anna była rozczarowana/rozzłoszczona/rozmarzona $z$ matka.

Anna.NOM was disappointed/angry/dreamy.PASS.PTCP.NOM with mother.INs

Negated passive structures still return structures with the same properties, as is the case with K-states, grammatical with temporal modifiers (30) (cf. (6) above), but ungrammatical with the remaining types of modifiers (31) (cf. (7) above):

(30) Anna nie była rozczarowana/rozzłoszczona/rozmarzona przez dwa Anna.NOM not was disappointed/angry/dreamy.PASS.PTCP.NOM for two dni.GEN/wczoraj. days/yesterday 'Anna was not disappointed/angry/dreamy for two days/yesterday'.

(31) Anna nie była rozczarowana/rozzłoszczona/rozmarzona Anna.Nom not was disappointed/angry/dreamy.PAss.PTCP.NOM * $(z$ matka $/ w$ domu $)$. with mother/at home 'Anna was not disappointed/angry/dreamy ${ }^{*}$ (with her mother/at home).'

Additionally, since K-states are objects without event implications, the existence of one object does not preclude the existence of another object at the same point in time, even if these objects have properties which logically exclude each other. Consequently, two K-states can be grammatically juxtaposed as existing simultaneously for the same holder in (32), while the same cannot be claimed about juxtaposed D-states with the events that exclude each other (33):

(32)
Dziewczyna była rozeźlona,
i jednocześnie
girl.NOM was angry.PASS.PTCP.NOM and at.the.same.time rozśmieszona.
exhilarated.PASS.PTCP.NOM
'The girl was angry and at the same time exhilarated.' 
(33) ${ }^{\star}$ Chłopak siedział $w$ parku i jednocześnie leżat. boy.NOM sat in park.LOC and at.the.same.time lay

'The boy sat in the park and at the same time lay'.

The phenomena discussed in this subsection point to the nature of roz-passives as K-states. In the next subsection we will discuss some problematic material which does not tally with their K-state status.

\subsection{Intrumental phrases as a problem for a K-state analysis of roz-passives}

Up to now we have discussed these features of passive structures with roz- participles which support their status as K-states. However, the data get more complicated when we consider a different class of arguments that enrich eventualities, i.e. instruments. In Polish instruments are most frequently expressed either by means of NPs in the instrumental case (34), or by phrases in the genitive case introduced by the preposition od 'from' (35):

(34) Anna rozbiła lustro młotkiem.

Anna.Nom broke mirror.ACC hammer.INs

'Anna broke the mirror with a hammer'

(35) Lustro pociemniało od kwasu.

mirror.NOM darkened from acid.GeN

'The mirror darkened from acid.'

While roz-statives cannot co-occur with the prepositional phrases introduced by $o d$ 'from' (36), as expected if they are K-states, they are grammatical with instrumental NPs (37): ${ }^{13}$

(36) *Anna była rozczarowana od złego losu. Anna.nom was disappointed.PAss.PTCP.NOM from bad.gen luck.geN 'Anna was disappointed because of her bad luck.'

(37) Tak byt roztkliwiony dobrocia Naczelnika, so was moved.PASS.PTCP.NOM goodness.INs Commander.GEN

ze łzy blyskały mu $\quad$ oczach.

that tears.NOM shone him.DAT in eyes.LOC

'He was feeling so tender because of the Commander's goodness that tiers shone in his eyes.'

Troche rozczulony jej dziecięcym zauroczeniem a bit touched.PASS.PTCP.NOM her.INs child-like.INs infatuation.INS 'Feeling a bit touched because of her child-like infatuation.'

${ }^{13}$ It is not clear whether $o d$ 'from' phrases represent instruments or causers. First, they cannot host typical instruments, but rather forces of nature or substances. Then, they only modify structures with middle predicates and copula clauses with adjectives used as predicates, so their occurrence may be limited due to other reasons. For a discussion of such constructions see Malicka-Kleparska (2017). 


Rozmarzony ciepłem pieca, opierat sie o
dreamy.PASS.PTCP.NOM warmth.INs
ramie towarzysza.

'Dreamy with the warmth of the oven, he leaned on his companion's arm.'

Kot rozleniwiony $\quad$ drzemka $w$ cieptym kacie.
cat.NOM lazy.PAss.PTCP.NOM slumber.INs in warm.LOC corner.LOC
'The cat, lazy from its slumber in a warm corner.'

As Maienborn $(2005,2019)$ maintains, one of the major properties of K-states consists in their failure to accommodate additional arguments, apart from the holder of a state. The Polish examples in (37) above, taken from NKJP, show that instrumental phrases can appear in the context of roz-passive participles. If these instrumental phrases are arguments in roz-passive structures, the Kimian status of our data will be undermined. ${ }^{14}$

The presence of instrumental phrases in the above sentences seems to contradict their K-state status. If we want to maintain the claim about the Kimian semantics of roz-passive participles, which is supported by a number of properties discussed in the previous subsection, we have to explain the strange behaviour of the instrumental phrases above.

\subsection{Analysis}

One way of dealing with the problem was prompted in 2019 by Bondaruk and Rozwadowska (11-14). These authors mention instrumental phrases as complements of basic verbs in passive adjectival structures with subclasses of OEVs. ${ }^{15}$ If instrumental phrases are indeed complements of basic verbs, inherited by passive participles in a lexicalised, frozen structure, then they may not count as 'additional' participants in a given eventuality and K-states might tolerate them. Below we quote one of the examples given by Bondaruk and Rozwadowska (2019: 11):

(38) Marek jest zainteresowany/zafascynowany fizyka.

Marek.NOM is interested/fascinated.PAss.PTCP.NOM physics.INs

'Marek is interested in/fascinated with physics.'

The phrase fizyka 'physics.Ins' represents the instrumental complement of the passive participle zainteresowany 'interested', or more precisely of the verbal stem. As the authors claim, it is not really an additional instrumental argument present in the predication, but the complement which performs

\footnotetext{
${ }^{14}$ The examples have been abbreviated due to space limitations. In fact the NKJP lists a few more examples with roz-participles and instrumental phrases, but both the participles and NPs are identical with these in (37).

${ }^{15}$ Bondaruk and Rozwadowska (2019) do not discuss roz- Experiencer verbs.
} 
the role of T (Theme) or SM (Subject Matter) of a psychological verb (cf. Pesetsky 1995).

The complement status of the instrumental phrase is supported by the application of a number of tests diagnosing complements. The tests have been adopted from Marelj (2016). They describe instrumental phrases as performing the function of arguments with T/SM properties. Marelj's tests can be carried over to roz-passives with instrumental NPs. If the instrumental phrases in the examples from NKJP test positively for being complements, we might pursue the line of reasoning proposed by Bondaruk and Rozwadowska (2019). If they do not, then either roz-passive structures are not K-states, but an altogether different kind of phenomena, with mixed $\mathrm{D}$-state and $\mathrm{K}$-state properties, or we have to propose a different analysis. Below we present the relevant tests as applied to roz- data.

The adopted tests consist in the possibility of pronominalizing the instrumental phrase (39), making the argument definite (40) and questioning it (41) (for details see Marelj 2016; Bondaruk and Rozwadowska 2019).

(39) Troche tym rozczulony.

a.bit this.INS touched.PASS.PTCP.NOM

'Feeling a bit touched with this.'

(40) Rozmarzony tym cieptem.

dreamy.PASS.PTCP.NOM this.INS warmth.INS

'Dreamy with this warmth.'
(41) Czym
rozmarzony?
(Tym ciepłem).
what.Ins dreamy.PASS.PTCP.NOM this.Ins warmth.INs
'Dreamy with what? (With this warmth.)'

(39) shows that the instrumental phrase can be pronominalized as tym 'this. INs', in (40) the instrumental phrase is made definite, (41) illustrates that the phrase can be questioned. The results univocally point to the complement-like status of the instrumental phrase in roz-passive structures.

However, there is a difference between our body of data and the statives discussed by Bondaruk and Rozwadowska (2019) and quoted above in (38), as in the case of all roz-passives the instrumental phrase is optional (cf. 14), while the passives of OEVs in Bondaruk and Rozwadowska's (2019) paper are ungrammatical without complementation. ${ }^{16}$ This fact prevents us from attributing the presence of instrumental phrases in passive roz-structures to

${ }^{16}$ Bondaruk and Rozwadowska (2019: 31) give such examples as: być zainteresowanym/zafascynowanym 'be interested/fascinated', which require an instrumental complement:

(i) ?Jan byt zainteresowany/zafascynowany.

Jan.NOM was interested/fascinated.PASs.PTCP.NOM

'Jan was interested/fascinated.' 
the specific complementation of OEVs. Thus we will not pursue this line of reasoning any further.

There is still another reason why we have decided not to treat instrumental phrases as complements in adjectival passives. Marelj (2016) directs our attention to a vital feature of complements, namely their relative independence in meaning from the predicate which they complement. The interpretation of complements is mediated through thematic roles apportioned by the predicate to its complement(s). In other words, the complement can be interpreted easily in a sentence through the thematic bond with its predicate. In the case of adjuncts, the semantic link has to be clearer since no thematic grid illuminates the role of an adjunct in predication. If we treat the instrumental phrases as adjuncts, we will expect some additional clues leading to their semantic interpretation.

Notice that the instrumental phrases in NKJP examples express essential properties for the state named in passive participial structures to occur or persist (cf. (37) above). Dobroć 'goodness' makes you feel touched, ciepło 'warmth' makes you feel dreamy, drzemka 'slumber' makes you feel lazy. Phrases which are not anchored in the meaning of roz-participles are inadmissible (42), while no such limitations hold in the case of events (43), not less unusual in their sense than (42). The instrumental phrase in (43) is an argument of the lexical verb and it has its thematic role ascribed in the predication:

(42) ${ }^{\star}$ Był rozmarzony mlotkiem. was dreamy.PASS.PTCP.NOM hammer.INS 'He was dreamy because of a hammer'.

(43) Bawit się młotkiem. played REFL hammer.INS 'He played with a hammer.'

Because instrumental NPs in roz- passives are not obligatory and they are semantically connected with participles, which distinguishes them from verbal complements, we would like to suggest a different solution concerning their nature. We claim that instrumental phrases accompanying roz-passive structures represent sortal concepts, which cannot clash in meaning with modified passive participles. The term sortal concepts has been borrowed from Trautwein (1970: 73), who defines them in the following way:

[sortal concepts] are not mental one-to-one mappings of the world. Rather they transport identifying conditions [...]. [W] need only a few conditions in order to identify a structure within a continuum, and these conditions are provided by sortal concepts. Sorts, however, are not able to identify individuals by themselves since the information they transport is too unspecific. But they reduce the set of possible referents drastically $[\ldots]$. 
The concepts introduced in instrumental phrases are such sortals, i.e. they reduce the freedom of semantic interpretations of the whole predication, or, in other words, they further delimit its meaning. In order to do that, sortals cannot jar with the meaning of a predication, but they have to be congruent with it. Thus the choice of sortals in instrumental phrases cannot be random, but it must correlate with the meaning of passive participles. As sortals are not additional participants in the predication, nor are they any other kind of modifiers banned by K-states, they are not precluded from appearing in roz-passives. Sortals identify subcategories of objects coded by K-states and they are adjuncts, not complements.

\section{Conclusion}

The purpose of this paper has been to investigate properties of structures with roz-passive participles in Polish as representing K-states. We have argued that the semantics of roz-passives as well as the formal properties of the structures fulfil the major criteria of K-states, as proposed by Maienborn $(2005,2019)$. A major problem for such an analysis is posed by modifying instrumental phrases, which should not appear with K-states. We have argued that these phrases are not arguments enriching the eventualities, but adjunct modifiers with sortal properties, unlike instrument arguments (complements), which are relatively freely associated with their heads meaning-wise.

\section{References}

Anderson Curt, Mokrzycki Marcin (2015). Degrees as kinds. Natural Language and Linguistic Theory 33, 791-828.

Arad Maya (1998). Psych-notes. UCL Working Papers in Linguistics 10, 1-22.

BAKER Mark (1988). Incorporation: A Theory of Grammatical Function Changing. Chicago: University of Chicago Press.

Belletti Adriana, Rizzi Luigi (1988). Psych-verbs and $\theta$ theory. Natural Language and Linguistic Theory 6, 291-352.

Bondaruk Anna, Rozwadowska Bożena, Witkowski Wojciech (2017). Passivisation of Polish object experiencer verbs vs. the unaccusativity hypothesis. Studies in Polish Linguistics 12, 57-73.

BondARUK Anna, RozwADOwska Bożena (2018). Stative and eventive passives of subject experiencer verbs in Polish. Poznań Studies in Contemporary Linguistics 54, 363-422.

Bondaruk Anna, Rozwadowska Bożena (2019). Polish object experiencer verbs in the stative and eventive passive. In All Around the Word. Papers in Honour of Bogdan Szymanek on his $65^{\text {th }}$ Birthday, Anna Bondaruk, Krzysztof JaskuŁA (eds.), 47-78. Lublin: Wydawnictwo KUL. 
Carlson Gregory (1977). Reference to Kinds in English. Amherst: University of Massachusetts. $\mathrm{PhD}$ dissertation.

Chierchia Gennaro (1995). Individual-level predicates as inherent generics. In The Generic Book, Gregory Carlson, Francis Pelletier (eds.), 176-223. Chicago: The University of Chicago Press.

DAVIDSON Donald (1967). The logical form of action sentences. In The Logic of Decision and Action, Nicholas Rescher (ed.), 81-95. Pittsburgh: University of Pittsburgh Press.

Dowty David (1979). Word Meaning and Montague Grammar. Dordrecht: Reidel.

ENGELBERG Stefan (2005). Kimian states and the grammar of predicative adjectives. Theoretical Linguistics 31, 331-347.

ERnst Thomas (2016). Modification of stative predicates. Language 92, 237-274.

Grafmiller Jason (2013). The Semantics and Syntactic Choice. An Analysis of English Emotion. Stanford: University of Stanford. PhD dissertation.

Grimshaw Jane (1990). Argument Structure. Cambridge, Ma.: The MIT Press.

Higginboтнам James (1983). The logic of perceptual reports: An extensional alternative to situation semantics. Journal of Philosophy 80, 100-27.

Higginвотнам James (1985). On semantics. Linguistic Inquiry 16, 547-593.

Higginbотнам James (2000). On events in linguistic semantics. In Speaking of Events, James Higginbotham, Fabio Pianesi, Achille Varzi (eds.), 49-79. Oxford: Oxford University Press.

Higginвотнам James (2005). Event positions: Suppression and emergence. Theoretical Linguistics 31, 349-358.

Higginbotнам James, Ramchand Gillian (1997). The stage-level/individual-level distinction and the Mapping Hypothesis. Oxford University Working Papers in Linguistics, Philology and Phonetics 2, 53-83.

KeEnAn Edward (1976). Towards a universal definition of subject. In Subject and Topic, Charles N. Li (ed.), 303-334. New York: Academic Press.

KIM Jaegwon (1976). Events as property exemplifications. In Action Theory, Myles Brand, Douglas Walton (eds.), 159-77. Dordrecht: Reidel.

LANDAU Idan (2010). The Locative Syntax of Experiencers. Cambridge, Ma.: The MIT Press.

LASKOWSKI Roman (1984). Kategorie morfologiczne języka polskiego - charakterystyka funkcjonalna [Morphological categories of the Polish language: A functional characteristic]. In Morfologia [Morphology], Renata Grzegorczykowa, Roman LAsKowski, Henryk Wróbel (eds.), 121-63. Warszawa: PWN.

LEVIN Beth (2009). Lexical semantics of verbs IV: Aspectual approaches to lexical semantic representation. Berkeley: University of California. Handout. https://web. stanford.edu/ bclevin/lsa09aspapp.pdf. Accessed December $2^{\text {nd }} 2020$.

MAIEnborn Claudia (2003). Die Logische Form von Kopula-Sätzen. Berlin: Akademie Verlag.

MAienborn Claudia (2004). A pragmatic explanation of stage level/individual level contrast in combination with locatives. In Proceedings of the Western Conference on Linguistics 15, Brian Agbayani, Vida Samiran, Benjamin Tucker (eds.), 158170. Fresno: CSU.

MAienborn Claudia (2005). On the limits of Davidsonian approach: The case of copula sentences. Theoretical Linguistics 31, 275-316. 
MaIEnborn Claudia (2007). On Davidsonian and Kimian states. In Existence: Semantics and Syntax, Ileana Comorovski, Klaus von Heusinger (eds.), 107-130. Dordrecht: Kluwer.

Maienborn Claudia (2019). Events and states. In The Oxford Handbook of Event Structure, Robert Truswell (ed.), 50-89. Oxford: Oxford University Press.

MaIEnborn Claudia, Schäfer Martin (2011). Adverbs and adverbials. In Semantics: An International Handbook of Natural Language Meaning 2, Klaus Heusinger, Claudia Maienborn, Paul Portner (eds.), 1390-1420. Berlin: Mouton de Gruyter.

Malicka-KLeparska Anna (2017). Middles in English and Polish. Lublin: Wydawnictwo KUL.

Malicka-Kleparska Anna (2019). Voice typology: A case of Polish adjectival passive participles related to Object Experiencer verbs in roz-. Studia Anglica Resoviensia $16,85-116$.

MARELJ Marijana (2016). In the South Slavonic garden: Landscaping the landscape of arguments and non-arguments. Linguistica 56, 193-209.

Moltmann Friederike (2007). Events, tropes and truthmaking. Philosophical Studies $134,363-403$.

PARsons Terence (1990). Events in the Semantics of English: A Study in Subatomic Semantics. Cambridge, Ma.: The MIT Press.

PArsons Terence (2000). Underlying events and time travel. In Speaking of Events, James Higginbotham, Fabio Pianesi, Achille Varzi (eds.), 81-93. Oxford: Oxford University Press.

Perlmutter David, Postal Paul (1984). The 1-advancement Exclusiveness Law. In Studies in Relational Grammar 2, David Perlmutter, Carol Rosen (eds.), 81-125. Chicago: University of Chicago Press.

Pesetsky David (1995). Zero Syntax: Experiencers and Cascades. Cambridge, Ma.: The MIT Press.

Przepiórkowski Adam, Bańko Mirosław, Górski Rafał, Lewandowska-Tomaszczyk Barbara (2012). Narodowy Korpus Języka Polskiego [The National Corpus of Polish]. Warszawa: PWN.

Ramchand Gillian (2005). Post-Davidsonianism. Theoretical Linguistics 31, 359-373.

Rothstein Susan (2004). Structuring Events. Oxford: Blackwell.

Rothstein Susan (2005). States and modification: A reply to Maienborn. Theoretical Linguistics 31, 375-381.

Smith Carlota (1999). Activities: States or events? Linguistics and Philosophy 22, 479-508.

Szajbel-Keck Malgorzata (2015). Secondary Predication in Polish. Berkley: University of California. PhD dissertation.

Szymanek Bogdan (2010). A Panorama of Polish Word-Formation. Lublin: Wydawnictwo KUL.

Trautwein Martin (1970). The Time Window of Language. Berlin: Mouton de Gruyter.

Vendler Zeno (1957). Verbs and times. Philosophical Review 56, 143-160.

WRóBEL Henryk (1984). Słowotwórstwo czasowników [Word-formation of verbs]. In Morfologia [Morphology], Renata Grzegorczy Kowa, Roman Laskowski, Henryk WróbEL (eds.), 467-506. Warszawa: PWN.

ZDZIEBKo Sławomir (2017). On the structure and interpretation of Polish passives. Acta Linguistica Academica 64, 563-617. 
Zhou Ziquian (2019). Neo-Davidsonian ontology of events. Linguistics and Philosophy. DOI: https://doi.org/10.1007/s10988-019-09292-5.

Anna Malicka-Kleparska

Katolicki Uniwersytet Lubelski Jana Pawła II

Al. Racławickie 14, 20-950 Lublin

malic(at)kul.pl 